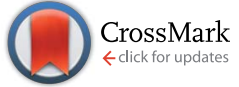

Cite this: RSC Adv., 2015, 5, 33524
Received 12th February 2015

Accepted 18th March 2015

DOI: $10.1039 / \mathrm{c} 5 \mathrm{ra02551f}$

www.rsc.org/advances

\section{Calix[4]arene amine modified silica: from fundamentals to new recyclable materials for the removal of chlorophenoxy acids from water}

\author{
Angela F. Danil de Namor, ${ }^{\text {a }}$ Jorge A. Zvietcovich-Guerra, ${ }^{a}$ Jose A. Villanueva Salas, ${ }^{a}$ \\ Oscar E. Piro, ${ }^{\text {b }}$ Oliver A. Webb, ${ }^{a}$ Abdelaziz El Gamouz, ${ }^{a}$ Weam Abou Hamdan ${ }^{a}$ \\ and Eduardo E. Castellano ${ }^{c}$
}

\begin{abstract}
Two molecular receptors based on calix[4]arenes and their interaction with chlorophenoxy acid herbicides in solution and in the solid state have been investigated. From ${ }^{1} \mathrm{H}$ NMR studies it is shown that the conformational changes of the receptor are directly related to the acid strength of the herbicide. Conductance data show that the interaction takes place through a proton transfer reaction from the herbicide to the receptor. This is also reflected in the solid state (X-ray crystallography). Based on these fundamental studies, these receptors were immobilised by grafting them into a silica based solid support. The extracting properties of calix[4]arene modified silica for these pollutants were investigated as a function of the $\mathrm{pH}$ of the aqueous solution and the capacities of these materials to remove these pollutants are reported. Titration calorimetry is for the first time explored to determine the factors (kinetics, mass/solution ratio and temperature) contributing to the optimal removal of herbicides from water. These materials can be easily recycled via a $\mathrm{pH}$ switching mechanism. After several recycling processes the extraction capacity of these materials remains at the level of $80-90 \%$ of the original value.
\end{abstract}

\section{Introduction}

The transfer of pollutants to surface and groundwater results from the movement of water in the soil. From the agricultural point of view herbicides are one of the main solutes to be found in water resources. Although these compounds fulfil an important role as far as agricultural productivity is concerned their presence in the ecosystem leads to serious health and environmental problems (extensively discussed in the literature). ${ }^{1-3}$ Among these herbicides phenoxyacids have been the subject of a wide range of investigations. Cho and co-workers investigated the toxicity of these herbicides using a variety of biomaterials ${ }^{4}$ while Argesse and coworkers used a sub-mitochondrial particle assay for assessing the toxicity of a number of phenoxyacid herbicides. ${ }^{5}$ The biodegradation of this family of herbicides has been studied by several workers. ${ }^{6}$ Technological approaches for the removal of phenoxyacid compounds from water have been the subject of numerous publications and for this purpose several materials have been

${ }^{a}$ Laboratory of Thermochemistry, Department of Chemistry, University of Surrey, Guildford, GU2 7XH, UK. E-mail: A.Danil-de-Namor@Surrey.ac.uk

${ }^{b}$ Departamento de Física, Facultad de Ciencias Exactas, Universidad Nacional de La Plata, Instituto IFLP (CONICET-UNLP), C.C. 67, 1900 La Plata, Argentina

'Instituto de Física de São Carlos, Universidade de São Paulo, C.P.369, 13560, São Carlos (SP), Brazil

$\dagger$ Electronic supplementary information (ESI) available. CCDC 950208. For ESI and crystallographic data in CIF or other electronic format see DOI: 10.1039/c5ra02551f explored..$^{7-14}$ Although the removal of herbicides by activated carbon has been used, it turned out that because of its lack of selectivity, this approach tends to remove not only the herbicides but also other useful water components.

The removal of pollutants using biologically active microorganisms and enzymes which decompose the pollutants into harmless species is also a known procedure. However these techniques can be expensive and are not widely applicable as micro-organisms and enzymes are not robust enough and are easily destroyed in harsh surroundings. Therefore this approach is unlikely to be suitable for the removal of toxic compounds such as phenoxy-acid herbicides.

Supramolecular Chemistry is the result of the chemical development that has taken place in the last four and half decades. ${ }^{15-18}$ One of its main features is selectivity. Among the many receptors developed during this period, calixarenes ${ }^{19-23}$ have attracted considerable attention due to the possibility of upper and lower rim functionalisation. Immobilisation of calixarenes into a solid support leads to the development of new materials thus avoiding the use of solvent extraction technology that although useful is environmentally unfriendly. The attachment of calix[4]arenes through their lower or upper rim to silica has been the subject of several papers ${ }^{24-28}$ and book chapters reported in the literature. ${ }^{25-30}$ In this paper we report solution ( ${ }^{1} \mathrm{H}$ NMR, conductance measurements) and solid state (structural X-ray diffraction) studies on the interaction of a lower rim partially 'tertiary amine' functionalised calix[4]arene, 
5,11,17,23-tetra-tert-butyl 25,27-bis(diethylamino)ethoxy-26,28dihydroxy calix[4]arene, $\mathbf{1}$, its fully substituted calix[4]arene counterpart: $\quad 5,11,17,23$-tetra-tert-butyl 25,26,27,28-(diethyllamino)ethoxy calix[4]arene, $2,{ }^{15-31}$ and their interaction with phenoxyacid herbicides.

This was followed by the synthesis and characterisation of two easily recyclable lower rim calix[4] arene amine-based silicates and their use for the removal of phenoxyacid herbicides from water. Herbicides investigated were: 2,4-dichlorophenoxyacetic acid, 2,4-D; 2-(2,4-dichlorophenoxy)propionic acid, 2,4DP; 4-(2,4-dichlorophenoxy)butyric acid, BU; 2-(2,4,5-trichlorophenoxy)propionic acid, 2-(2,4,5-T); 2,3,6-trichlorophenyl acetic acid, 2,3,6-T; and, 1-naphtalene acetic acid, NAA (Fig. 2).

\section{Results and discussion}

\section{Selecting the receptor}

Among the various calix[4]arene derivatives tested, $\mathbf{1}$ and $\mathbf{2}$ showed the highest affinity with the proton. ${ }^{31}$ Due to the very low solubility of the receptors in water, ${ }^{1} \mathrm{H}$ NMR measurements were carried out to assess the interaction between 1 and the herbicides in a dipolar aprotic solvent, deuterated acetonitrile $\left(\mathrm{CD}_{3} \mathrm{CN}\right)$, and in a protic solvent, deuterated methanol $\left(\mathrm{CD}_{3} \mathrm{OD}\right)$. Except for NAA and BU for which no chemical shift changes were observed, significant downfield chemical shift changes relative to the free receptor (proton numbers for the receptor are shown in Fig. 1) were observed for H-7 (0.16-0.20 ppm), H-8 (0.34-0.45 ppm), H-9 $(0.30-0.38 \mathrm{ppm})$ and to a lesser extent $\mathrm{H}-10(0.14-0.18 \mathrm{ppm})$ for 2,4-D. 2,4-DP, 2,4,5 $\mathrm{T}$ and 2,4,5-T in $\mathrm{CD}_{3} \mathrm{CN}$. For 2,3,6-T smaller changes were observed for $\mathrm{H}-8$ and $\mathrm{H}-9(0.12 \mathrm{ppm})$ in this solvent. In $\mathrm{CD}_{3} \mathrm{OD}$ similar chemical shift changes are observed. Unlike $\mathrm{CD}_{3} \mathrm{CN}$, chemical shift changes in $\mathrm{H}-8$ (0.17-0.20 ppm), H-9 (0.28-0.32 ppm) and $\mathrm{H}-10(0.10-0.11 \mathrm{ppm})$ relative to the free receptor were found for NAA and BU in this solvent. The results indicate that interaction takes place between the amine nitrogen of the receptor and the carboxylic proton of the herbicide either through hydrogen bond formation or a proton transfer reaction.

Substantial evidence of the conformational changes that $\mathbf{1}$ undergoes upon interaction with the herbicide in $\mathrm{CD}_{3} \mathrm{CN}$ and $\mathrm{CD}_{3} \mathrm{OD}$ solvents are the differences (in ppm) between the chemical shifts of the axial and the equatorial protons $\left(\Delta \delta_{\mathrm{ax}-\mathrm{eq}}\right)$. Thus these differences decrease significantly relative to the corresponding ones for the free ligand. According to Gutsche ${ }^{21}$ a $\Delta \delta_{\text {ax-eq }}=0.90 \mathrm{ppm}$ value is indicative that the calix receptor is in a perfect 'cone' conformation. It follows that $\mathbf{1}$ seems to be in an
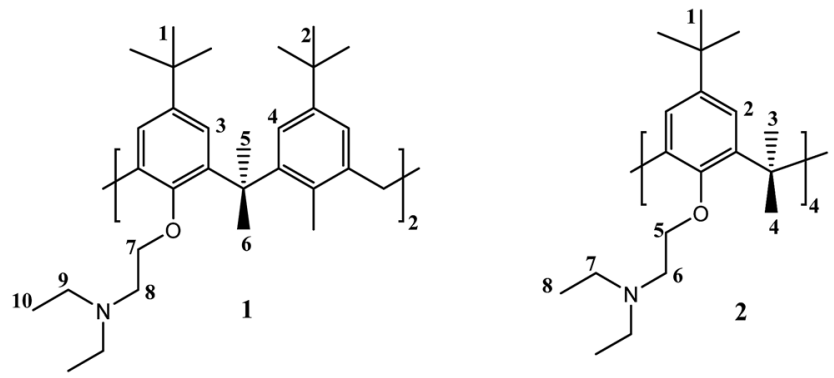

Fig. 1 Structures of receptors 1 and 2 with proton numbers.<smiles>O=C(O)COc1ccc(Cl)cc1Cl</smiles><smiles>CC(Oc1ccc(Cl)cc1Cl)C(=O)O</smiles><smiles>CC(C)(C)CCCOc1ccc(Cl)cc1Cl</smiles><smiles>CC(Oc1cc(Cl)c(Cl)cc1Cl)C(=O)O</smiles><smiles>O=C(O)Cc1c(Cl)ccc(Cl)c1Cl</smiles><smiles>Cc1cccc(CC(=O)O)c1CC(=O)O</smiles>

Fig. 2 The chemical structures of the herbicides studied.

almost perfect 'cone' conformation $\left(\Delta \delta_{\text {ax-eq }}=1.00\right.$ and $0.95 \mathrm{ppm}$ in $\mathrm{CD}_{3} \mathrm{CN}$ and $\mathrm{CD}_{3} \mathrm{OD}$, respectively). The results suggest that the receptor alters its conformation upon interaction with the herbicides from a 'cone' to a distorted 'cone' in both solvents. In an attempt to explain the variations observed in the $\Delta \delta_{\text {ax-eq }}$ values for the various herbicides, these values were plotted against the $\mathrm{p} K_{\mathrm{a}}$ values of these guests in water. ${ }^{32}$ Strictly speaking, $\mathrm{p} K_{\mathrm{a}}$ values in acetonitrile and methanol should be considered but these data are not available. However it is expected that the $\mathrm{p} K_{\mathrm{a}}$ values in a
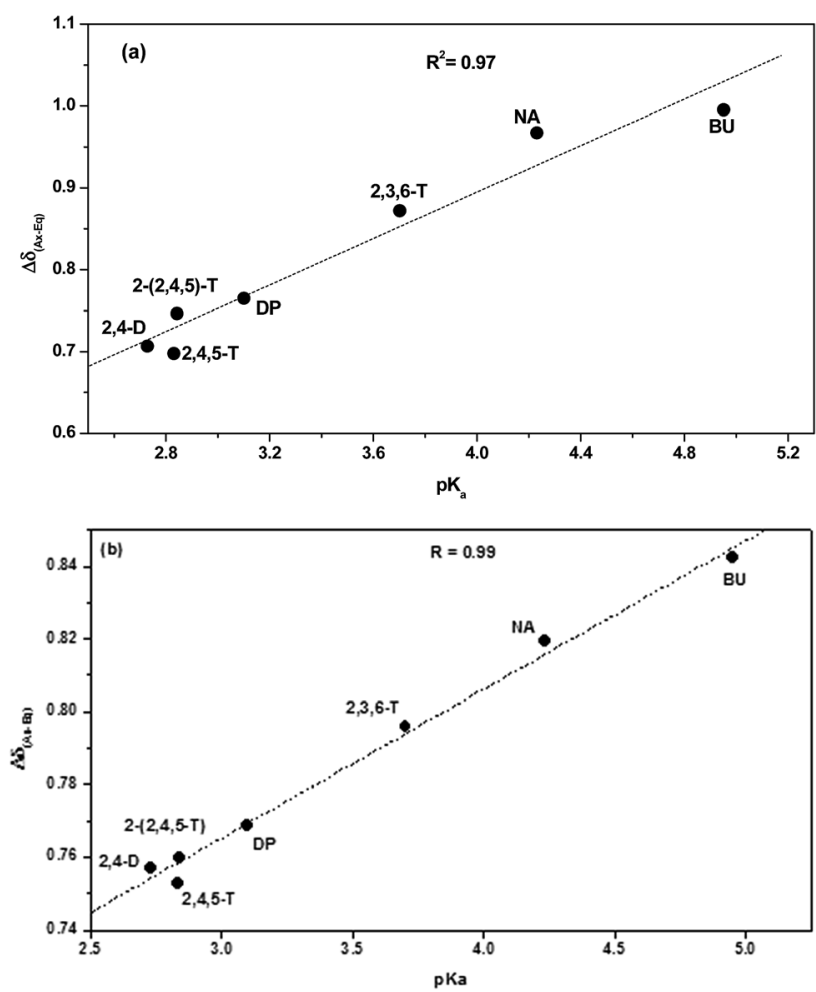

Fig. 3 Plots of $\Delta \delta_{\text {ax-eq }}$ values of 1 in $\mathrm{MeCN}$ (a) and $\mathrm{MeOH}$ (b) at $298 \mathrm{~K}$ against $p K_{a}$ values of herbicides in water. 
non-aqueous solvent would follow the same trend as those in water, although the absolute $\mathrm{p} K_{\mathrm{a}}$ values will differ due to the medium effect. Plots of $\Delta \delta_{\text {ax-eq }}$ values for the various herbicides in $\mathrm{CD}_{3} \mathrm{CN}$ and $\mathrm{CD}_{3} \mathrm{OD}$ against their $\mathrm{p} K_{\mathrm{a}}$ values in water at $298 \mathrm{~K}$ are shown in Fig. 3. The lineal correlations found demonstrate that as the $\mathrm{p} K_{\mathrm{a}}$ value increases, $\Delta \delta_{\mathrm{ax}-\mathrm{eq}}$ decreases. Therefore the conformational changes of the receptor are directly related to the acid strength of the phenoxy acid herbicide.

Following ${ }^{1} \mathrm{H}$ NMR studies, conductometric titrations were carried out to assess whether the interaction takes place through hydrogen bond formation or a proton transfer reaction. If the latter process predominates, then ions will be present in solution. Representative conductometric curves (plots of molar conductance, $\Lambda_{\mathrm{m}} / \mathrm{S} \quad \mathrm{cm}^{2} \quad \mathrm{~mol}^{-1}$ against the ligand : acid concentration ratio) for the titration of 2,4-D with 1 in acetonitrile and methanol at $298.15 \mathrm{~K}$ are shown in Fig. 4. Inspection of these titration curves shows that at the ligand : acid ratio = 0 the herbicide in these solvents is un-dissociated $\left(\Lambda_{\mathrm{m}} \sim 0 \mathrm{~S} \mathrm{~cm}^{2}\right.$ $\mathrm{mol}^{-1}$ ). As the titration proceeds there is a marked increase in $\Lambda_{\mathrm{m}}$ values (from $\mathbf{A}$ to $\mathbf{B}$ ) with a clear break at the molar concentration of 0.5 , thus indicating that two protons are
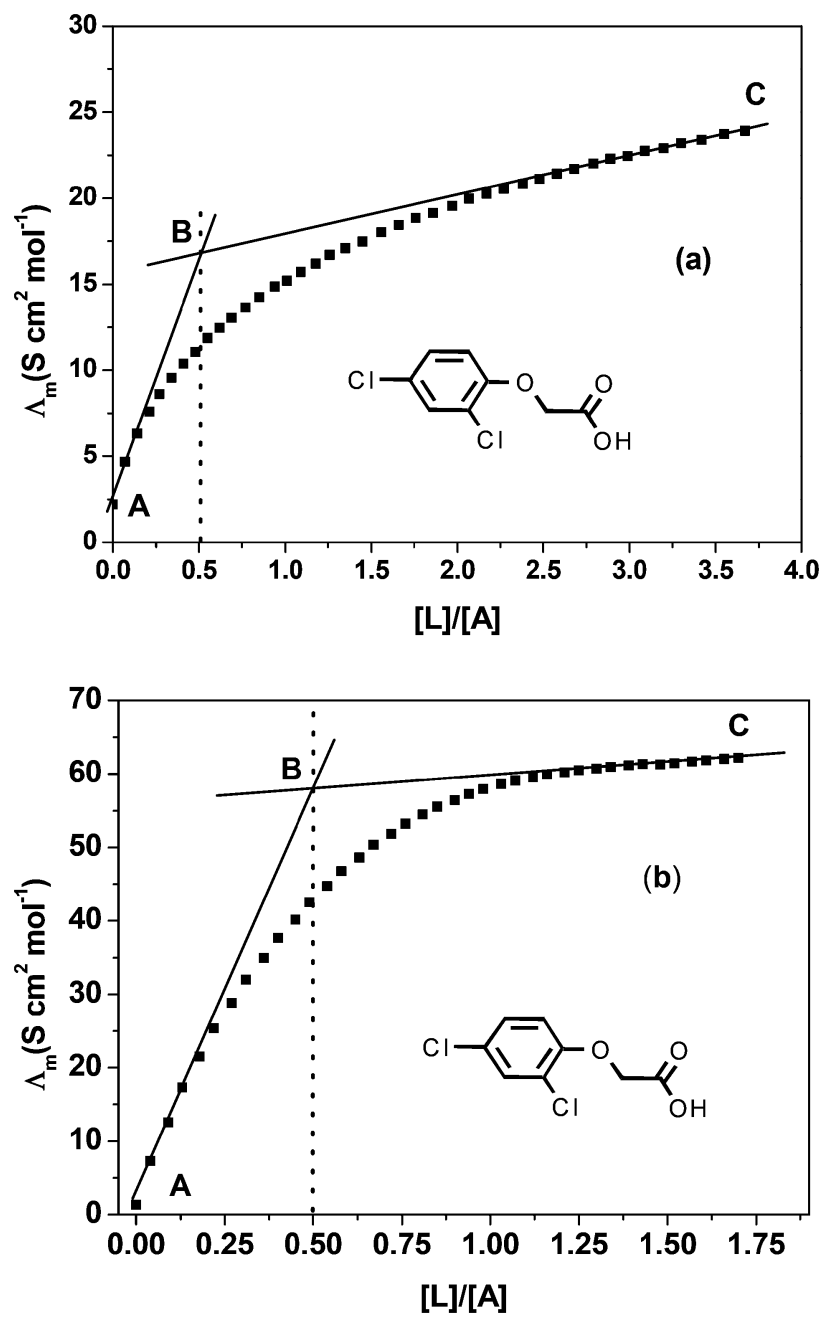

Fig. 4 Conductometric curves for the titration of 2,4-D with 1 in acetonitrile (a) and methanol (b) at $298.15 \mathrm{~K}$. taken up for each receptor. This increase in conductance reflects that the addition of the receptor (non-electrolyte) to the herbicide substantially increases ion formation in solution. This is attributed to a proton transfer reaction from the acid to the receptor. From $\mathbf{B}$ to $\mathbf{C}$ there is a further increase in conductance.

The addition of an excess of $\mathbf{1}$ to the solution displaces the equilibrium (eqn (1)) to the right and the conductance slightly increases.

$$
2 \mathrm{H}^{+}(\mathrm{s})+\mathbf{1}(\mathrm{s}) \rightarrow\left[\mathrm{H}_{2} \mathbf{1}\right]^{2+}(\mathrm{s})
$$

In eqn (1), s denotes the solvent (acetonitrile or methanol). Proton transfer reactions also occur with 2 and these herbicides but the break is found at the concentration ratio of 0.25 hence showing that four protons are taken up per unit of receptor. In an attempt to investigate further the herbicide-receptor interaction, we proceeded with the isolation of the complex. Suitable crystals for structural X-ray diffraction studies were obtained and the results are now discussed.

\section{Structural results and discussion}

Fig. 5 shows an ORTEP ${ }^{33}$ plot of the solid state supramolecular adduct of partially functionalised and double protonated $\mathbf{1 H}_{2}{ }^{2+}$ calixarene with a pair of deprotonated 2,4-D herbicide molecules

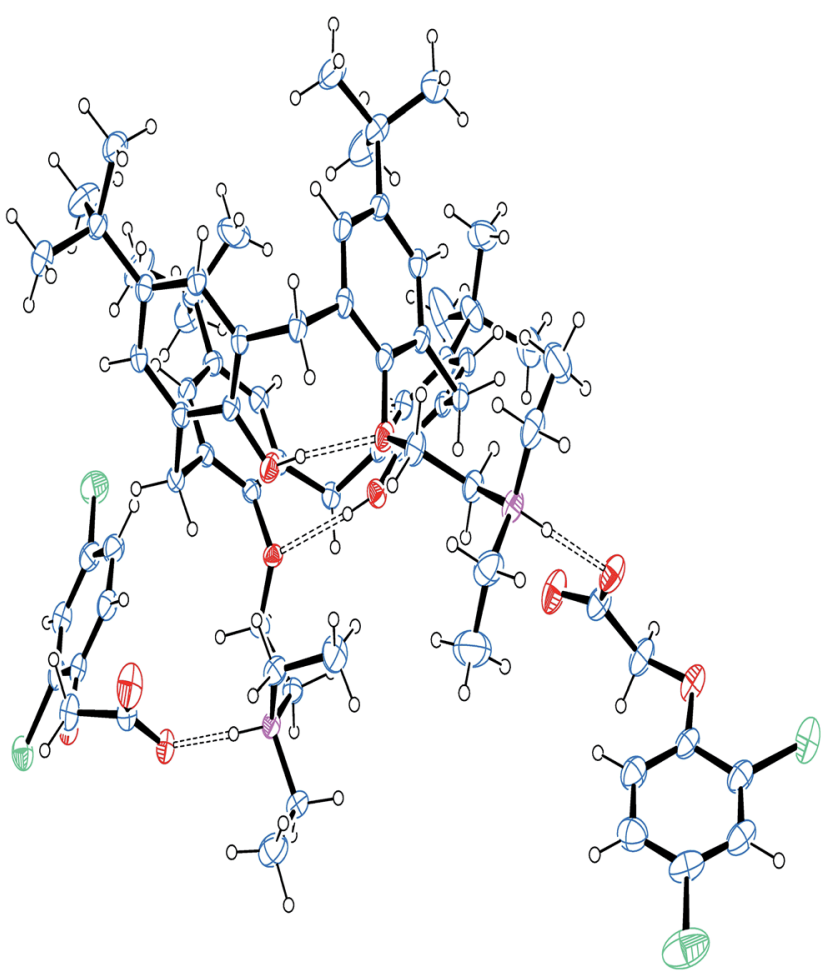

Fig. 5 View of the solid state 5,11,17,23-tetra-tert-butyl[25,27-dihydroxy-26,28-bis(diethylamineH)ethoxy]calix[4]arene 1 complex with two herbicide 2,4-D molecules showing the atomic displacement ellipsoids at the $30 \%$ probability level. Blue, red, violet and green ellipsoids denote carbon, oxygen, nitrogen and chlorine atoms, respectively. $\mathrm{H}$-bonds are indicated by dashed lines. The crystallization water molecule has not been included. 
$\left(\mathrm{PhCl}_{2} \mathrm{OCH}_{2} \mathrm{COO}^{-}\right)$, namely $\mathbf{1 H}_{2}\left(\mathrm{PhCl}_{2} \mathrm{OCH}_{2} \mathrm{COO}\right)_{2}$ complex. The calixarene hydrophobic cavity shows a distorted 'cone' conformation with the opposite phenyl rings carrying the pendant arms being close to parallelism with each other [dihedral angle of $\left.18.7(2)^{\circ}\right]$ and the other opposite phenyl rings with hydroxyl groups attached to them at the lower bore being near perpendicular to each other [angled at 88.77(9) ${ }^{\circ}$ ]. Both hydroxyl groups form intramolecular H-bonds with the phenolic oxygen atom of an adjacent pendant arm [O(ox) $\cdots \mathrm{O}(\mathrm{ph})$ distances of 2.783 and $2.816 \AA$ and O$\mathrm{H} \cdots \mathrm{O}(\mathrm{ph})$ angles of 163.8 and $161.7^{\circ}$, respectively].

The positively charged $1 \mathrm{H}_{2}{ }^{2+}$ calixarene derivative binds two negatively charged $\mathrm{PhCl}_{2} \mathrm{OCH}_{2} \mathrm{COO}^{-}$herbicide molecules at the periphery of the hydrophilic cavity through a pair of strong and linear intermolecular $\mathrm{N}-\mathrm{H} \cdots \mathrm{O}$ bonds (see Fig. 5). These bonds involve the pendant amine groups and one of the herbicide carboxylate oxygen atoms [N $\cdots$ O distances of 2.666 and $2.715 \AA$ and corresponding $\mathrm{N}-\mathrm{H} \cdots \mathrm{O}$ angles of 171.3 and $\left.178.6^{\circ}\right]$.

As expected, the herbicide $\mathrm{PhCl}_{2} \mathrm{O}$ molecular fragments are planar [rms deviation of atoms from the best least-squares plane less than $0.033 \AA$ ] . The terminal -O- $\left(\mathrm{CH}_{2}\right)-\mathrm{COO}$ groups show considerable flexibility due to rotations around the $\sigma$ bonds, a fact that affords the optimal $\mathrm{N}-\mathrm{H} \cdots \mathrm{O}$ bond observed along an oxygen lone pair laying on the carboxylate plane in both herbicide molecules [C-O $\cdots \mathrm{H}$ angles of 117.4 and $108.7^{\circ}$ ].

The crystal is further stabilised by an intermolecular $\mathrm{Ow}^{-}$ $\mathrm{H} \cdots \mathrm{O}$ bond involving as donor the crystallisation water molecule and as acceptor a carboxylate oxygen atom of one herbicide molecule $\left[d(\mathrm{Ow} \cdots \mathrm{O})=2.891 \AA, \angle(\mathrm{Ow}-\mathrm{H} \cdots \mathrm{O})=156.6^{\circ}\right]$.

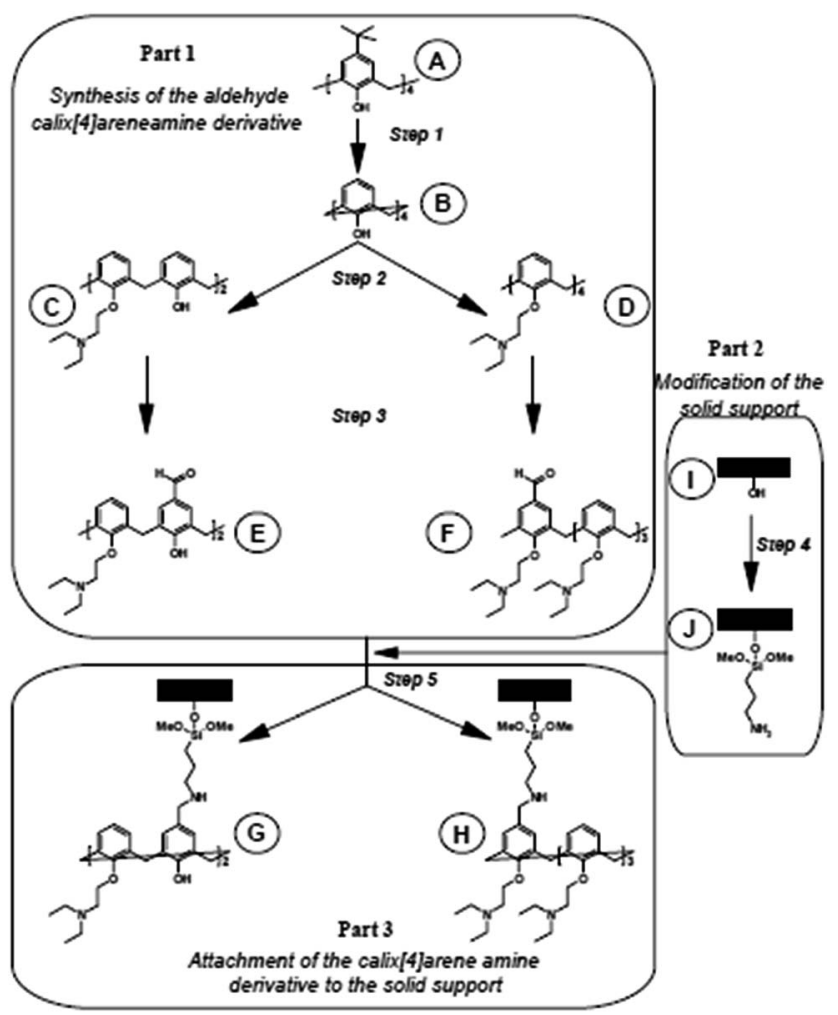

Scheme 1 Synthetic procedure for the attachment of the receptor to the solid support.

\section{Attachment of the calix[4]arene amine derivatives to a solid support}

The attachment of the receptor to the silica (Scheme 1) was carried out through the $p$-position of both receptors: 1 and 2 . This position was selected with the aim of leaving the pendant arms of the macrocycle relatively free to interact with the herbicides.

The synthetic procedure is divided into three main parts,

(i) Synthesis of the calix[4] arene derivatives with an aldehyde moiety in the upper rim of the calix[4] arene receptors, $\mathbf{E}$ and $\mathbf{F}$ (steps 1, 2 and 3 in Scheme 1).

(ii) Modification of the solid support by the insertion of a suitable functional group (J) which has a double function: to serve as an spacer unit and as a link between the calix[4]arene receptor and the solid support (step 4 in Scheme 1).

(iii) Attachment of the receptors to the solid support, $\mathbf{G}$ and $\mathbf{H}$ (step 5 in Scheme 1).

Each of these steps is described in the Experimental part, steps 1, 2 and 3 were characterised by ${ }^{1} \mathrm{H}$ NMR and microanalysis. The content of amine groups for the modified silica (J) quantified by acid-base back titration ${ }^{27}$ was found to be $0.75 \mathrm{mmol} \mathrm{g}^{-1}$ of material. Taking into account that the nitrogen value reported in the microanalysis represents the total percentage of the primary amine attached on the silica surface, it follows that the amino group content of $\mathbf{J}$ calculated from microanalysis was $0.71 \mathrm{mmol}$ $\mathrm{g}^{-1}$ in good agreement with the value obtained from the acidbase back titration. For the calix[4]arene modified silicas the total amine group contents were $1.60 \pm 0.03$ and $1.81 \pm 0.04 \mathrm{mmol}$ $\mathrm{g}^{-1}$, respectively. Therefore the amount of nitrogen content due to the calix[4]arene groups in $\mathbf{G}$ and $\mathbf{H}$ were 0.85 and 1.06 respectively. As far as the IR spectra is concerned, for the unmodified silica, a large broad band between 3200 and 3400 $\mathrm{cm}^{-1}$ was attributed to the presence of the $\mathrm{OH}$ stretching frequency of silanol groups and also to the remaining sorbed water. The broad and intense band at $1040 \mathrm{~cm}^{-1}$ was assigned to the siloxane vibration $(\mathrm{Si}-\mathrm{O}-\mathrm{Si})$, while the $\mathrm{Si}-\mathrm{O}$ bond stretching was detected at $958 \mathrm{~cm}^{-1}$. Other bands at 801 and $472 \mathrm{~cm}^{-1}$ were due to $\mathrm{Si}-\mathrm{O}-\mathrm{Si}$ stretching and $\mathrm{Si}-\mathrm{O}-\mathrm{Si}$ bending, respectively. In the spectra of all modified silicas, the new bands at 2961 and 2870 $\mathrm{cm}^{-1}$ are assigned to the symmetrical and asymmetrical $(\mathrm{C}-\mathrm{H})$ stretching frequency. These are due to the presence of the carbon chain of APTMS spacer groups. After functionalisation by amino calix[4]arene organic moieties, the new band at around between $1600 \mathrm{~cm}^{-1}$ and $1400 \mathrm{~cm}^{-1}$ were ascribed to aromatic vibration bands of the calix[4]arene platform.

Having characterised these materials, extraction experiments were carried out to demonstrate the efficiency of the calix [4]arene modified silicas to remove herbicides from water and the results are discussed below.

\section{Extraction of phenoxy acid herbicides from water}

The pH effect. It is expected that the amino moieties in the silica material are protonated below $\mathrm{pH} 9-10$, while between $\mathrm{pH}$ 1-3 the predominant species of 2,4-D herbicide in aqueous medium will be the undissociated forms given that $\mathrm{p} K_{\mathrm{a}}$ is $2.6-$ 3.4. Therefore the percentage of herbicide extracted by the material is indeed low. As the amount of dissociated acid 
increases by an increase in the $\mathrm{pH}$ of the aqueous solution, the percentage of herbicide removed increases to an extent that the maximum percentage of extraction is found at $\mathrm{pH}=3$. However at $\mathrm{pH}$ values of 9 or higher, the amount of the protonated amine in silica $\mathbf{H}$ decreases. As a result the removal properties of the silica material decreases. Thus at $\mathrm{pH} 9$, the ability of this material to extract the acid is significantly reduced. The conclusion that can be drawn here is that the maximum percentage of extraction of 2,4-D herbicide occurs at the $\mathrm{pH}$ close to the $\mathrm{p} K_{\mathrm{a}}$ of this compound in solution, therefore all extraction experiments involving other herbicides were carried out in a $\mathrm{pH}$ closer to the $\mathrm{p} K_{\mathrm{a}}$ of each specific herbicide.

Removal capacity of the materials. The extraction capacity of these materials in $\mathrm{mmol} \mathrm{g}^{-1}$ and $\mathrm{mg} \mathrm{g}^{-1}$ of material for the various herbicides is shown in Table 2 . The results shown in this table lead to the following conclusions,

(i) The extraction capacity of the fully substituted calix[4]arene amine silica $(\mathbf{H})$ is about twice of that of the partially substituted calix[4]arene amine silica (G) as implied by the fact that there are two additional amine groups in the former relative to the latter. It is therefore concluded that the $\mathrm{NH}$ group of the modified silica although able to interact in its free state (J) must be somehow hindered by the presence of the calixarene amine in the silica structure.

(ii) The removal capacity of each of these materials is not significantly altered with the herbicide.

Table $1 \mathrm{Crystal}^{a}$ data and structure refinement for
$1 \mathrm{H}_{2}\left(\mathrm{PhCl}_{2} \mathrm{OCH} \mathrm{COO}_{2} \cdot \mathrm{H}_{2} \mathrm{O}\right.$ a

Empirical formula
Formula weight
Temperature
Wavelength
Crystal system
Space group
Unit cell dimensions

Final $R$ indices $^{a}[I>2 \sigma(I)]$
Volume

$Z$, density (calculated)

Absorption coefficient

$F(000)$

Crystal size

$\vartheta$-range for data collection

Index ranges

Reflections collected

Independent reflections

Observed reflections $[I>2 \sigma(I)]$

Completeness to $\vartheta=22.73^{\circ}$

Max. and min. transmission

Refinement method

Data/restraints/parameters

Goodness-of-fit on $F^{2}$

$R$ indices (all data)

Largest diff. peak and hole

$\mathrm{C}_{72} \mathrm{H}_{96} \mathrm{Cl}_{4} \mathrm{~N}_{2} \mathrm{O}_{11}$
1307.31
$200(2) \mathrm{K}$
$0.71073 \AA$
Monoclinic
$P 2{ }_{1} / n(\# 14)$
$a=22.256(1) \AA$
$b=14.171(1) \AA$
$c=24.719(1) \AA$
$b=111.97(1)^{\circ}$
$7230.0(7) \AA^{3}$
$4,1.201 \mathrm{Mg} \mathrm{m}^{-3}$
$0.221 \mathrm{~mm}{ }^{-1}$
2792
$0.24 \times 0.20 \times 0.06 \mathrm{~mm}^{3}$
2.84 to $22.73^{\circ}$
$-24 \leq h \leq 21,-14 \leq k \leq 15$,
$-26 \leq l \leq 26$
35991
$9710[R($ int $)=0.0646]$
7142
$99.7 \%$
0.9869 and 0.9488
$F u l 1-\mathrm{m}^{\circ}$

Full-matrix least-squares on $F^{2}$

$9710 / 15 / 842$

1.006

$R_{1}=0.0500, \mathrm{w} R_{2}=0.1256$

$R_{1}=0.0748, \mathrm{w} R_{2}=0.1474$

0.353 and -0.365 e $\AA^{-3}$

${ }^{a} R_{1}=\sum|| F_{\mathrm{o}}|-| F_{\mathrm{c}}|| / \sum\left|F_{\mathrm{o}}\right|, \mathrm{w} R_{2}=\left[\sum \mathrm{w}\left(\left|F_{\mathrm{o}}\right|^{2}-\left|F_{\mathrm{c}}\right|^{2}\right)^{2} / \sum \mathrm{w}\left(\left|F_{\mathrm{o}}\right|^{2}\right)^{2}\right]^{1 / 2}$.
Table 2 Extraction capacity of partially and fully substituted calix[4] arene amine silicas for phenoxyacid herbicides

\begin{tabular}{|c|c|c|c|c|}
\hline \multirow[b]{2}{*}{ Herbicide } & \multicolumn{2}{|c|}{$\begin{array}{l}\text { Partially substituted calix }[4] \\
\text { arene modified silica }(\mathbf{G})\end{array}$} & \multicolumn{2}{|c|}{$\begin{array}{l}\text { Fully substituted calix }[4] \\
\text { arene modified silica }(\mathbf{H})\end{array}$} \\
\hline & $\begin{array}{l}\text { Capacity } \\
\left(\mathrm{mmol} \mathrm{g}^{-1}\right)\end{array}$ & $\begin{array}{l}\text { Capacity } \\
\left(m g g^{-1}\right)\end{array}$ & $\begin{array}{l}\text { Capacity } \\
\left(\mathrm{mmol} \mathrm{g}^{-1}\right)\end{array}$ & $\begin{array}{l}\text { Capacity } \\
\left(\mathrm{mg} \mathrm{g}^{-1}\right)\end{array}$ \\
\hline 2,4-D & 0.27 & 59.64 & 0.55 & 121.55 \\
\hline $2-(2,4-D P)$ & 0.25 & 58.72 & 0.57 & 133.93 \\
\hline $4-(2,4-\mathrm{DB})$ & 0.26 & 64.71 & 0.55 & 136.95 \\
\hline NAA & 0.24 & 44.64 & 0.54 & 100.44 \\
\hline
\end{tabular}

The next section discusses the use of titration calorimetry to determine the optimal conditions for the removal process.

Calorimetry as a valuable tool to assess the optimum conditions for the removal process. Calorimetric titrations were performed with the aim of assessing, (i) the mass/solution ratio (ii) the kinetics of the extraction process, an extremely relevant parameter to consider (iii) the effect of temperature (iv) the impact of the amino calix[4]arene on silica relative to the unmodified silica material.

Thus the heat of immersion, (known as the heat produced or absorbed when a certain amount of the dry solid material enters in contact with water), was measured by calorimetry. To this purpose, ampoules containing a known mass of dry solid material in a known volume of water at $298.15 \mathrm{~K}$ were broken in the calorimeter vessel. Heat of immersion of the unmodified silica in water and in the presence of the herbicide and modified silica (G) were determined at $298.15 \mathrm{~K}$. These data are reported in Table 3 . It can be seen from this table that an exothermic process took place when the unmodified and modified silica came into contact with water due to the hydration of the materials. An important issue to address here is the lack of interaction of the unmodified silica in the presence of the herbicide given that the heats of immersion are practically the same within the experimental error in water $\left(-50 \pm 2 \mathrm{~J} \mathrm{~g}^{-1}\right.$, Table 3, column 2) than in the aqueous solution containing the herbicide $\left(-49 \pm 1 \mathrm{~J} \mathrm{~g}^{-1}\right.$, Table 3 , column 6$)$ a fact that reflects the lack of unmmodified silica-herbicide interaction. No significant changes in the heat of immersion were also found

Table 3 Heats of immersion of silica gel and modified silicas in water at $298.15 \mathrm{~K}$

\begin{tabular}{|c|c|c|c|c|c|}
\hline \multicolumn{2}{|c|}{$\begin{array}{l}\text { Unmodified silica in } \\
\text { water }\end{array}$} & \multicolumn{2}{|c|}{$\begin{array}{l}\text { Partially substituted } \\
\text { calix[4]arene } \\
\text { modified silica (G) }\end{array}$} & \multicolumn{2}{|c|}{$\begin{array}{l}\text { Unmodified silica in } \\
\text { an aqueous solution } \\
\text { of } 2,4 \mathrm{D}\end{array}$} \\
\hline$m(\mathrm{~g})$ & $Q_{\mathrm{i}}\left(\mathrm{J} \mathrm{g}^{-1}\right)$ & $m(\mathrm{~g})$ & $Q_{\mathrm{i}}\left(\mathrm{J} \mathrm{g}^{-1}\right)$ & $m(\mathrm{~g})$ & $Q_{\mathrm{i}}\left(\mathrm{J} \mathrm{g}^{-1}\right)$ \\
\hline 0.0097 & -47.85 & 0.0044 & -56.98 & 0.0059 & -48.75 \\
\hline 0.0167 & -49.18 & 0.0059 & -57.32 & 0.0132 & -49.94 \\
\hline 0.0285 & -52.98 & 0.0132 & -55.57 & 0.0378 & -50.33 \\
\hline 0.0517 & -50.25 & 0.0378 & -57.64 & 0.0409 & -47.77 \\
\hline 0.0099 & -47.27 & 0.0409 & -56.22 & 0.0482 & -48.09 \\
\hline 0.0029 & -51.32 & 0.0482 & -59.11 & 0.0059 & -48.75 \\
\hline Average & $-50 \pm 2$ & Average & $-57 \pm 1$ & Average & $-49 \pm 1$ \\
\hline
\end{tabular}


with the mass of the solid material. However this is not the case for the modified silica in contact with water (Table 3, column 4) where the exothermic character of the immersion process increases which may be attributed to hydration of the materials which is expected to be more pronounced in the modified than in the unmodified material.

When a certain amount of dry partially substituted calix[4] arene amino modified silica (1) was immersed in an aqueous solution containing a known concentration of 2,4-dichlorophenoxyacetic acid (2,4-D), heat changes were observed. Thus the heat known as gross or total heat $\left(Q_{\mathrm{t}}\right)$ involves the heat due to: (i) the reaction of the solid material with the acid herbicide, $Q_{\mathrm{r}}$; (ii) the immersion of the solid material in water, $Q_{\text {imm }}$; (iii) the breaking of the ampoule, $Q_{\mathrm{ab}}$. From these data, the heat produced by the reaction between the chlorophenoxy acid and the dry modified silica was calculated by subtracting from $Q_{\mathrm{t}}$, the values of $Q_{\text {inm }}$ and $Q_{\mathrm{ab}}$.

Table 4 reports the enthalpy of the acid herbicide uptake per gram of material $(\Delta H)$, the percentage of extraction $(\% E)$, and the mass of the solid material used in each experiment. It is important to mention that the initial concentration of herbicide was $5.89 \times 10^{-4} \mathrm{~mol} \mathrm{dm}^{-3}$ and the heat due to the immersion of the material in water is the value reported in Table 3. The enthalpy of extraction of the acid herbicide by the solid material at 298.15 K was evaluated from the average value at one hundred percent of the reaction, once corrections for the heat of immersion of the solid material in water and the heat of ampoule breaking were applied to the total heat obtained. The decrease of the exothermic character of the enthalpy of extraction of the acid herbicide from aqueous solution by the material $\left(-9.2 \pm 0.6 \mathrm{~kJ} \mathrm{~mol}^{-1}\right)$ is attributed to the possible dehydration of the herbicide (endothermic process) when entering the material which partially overcomes the herbicide-modified silica interaction. From these data it is concluded that the optimum mass/solution ratio was $6 \mathrm{mg}$ of material/50 $\mathrm{ml}$ of solution (i) the kinetics of the process was very fast, the reaction was complete in a few minutes (ii) the fact that the process is exothermic is indicative that as the temperature increases the

Table 4 Heats of extraction of aqueous 2,4-dichlorophenoxy acetic acid $(2,4-D)$ solution by partially substituted calixarene modified silica (H) at $298.15 \mathrm{~K}$

\begin{tabular}{lll}
\hline$m(\mathrm{~g})$ & $\% E$ & $\Delta H\left(\mathrm{~kJ} \mathrm{~g}^{-1}\right)$ \\
\hline 0.0082 & 99.85 & -9.95 \\
0.0080 & 99.84 & -9.28 \\
0.0076 & 99.72 & -9.43 \\
0.0074 & 99.82 & -8.79 \\
0.0068 & 99.86 & -8.40 \\
0.0061 & 99.87 & -7.59 \\
0.0059 & 99.86 & -7.35 \\
0.0054 & 96.76 & -5.93 \\
0.0046 & 87.04 & -4.02 \\
0.0041 & 82.99 & -3.15 \\
0.0028 & 76.51 & -1.59 \\
0.0019 & 65.99 & -0.31
\end{tabular}

removal of herbicides by the material decreases (iii) the unmodified silica does not interact with the herbicide.

Percentage of removal of herbicides from water by modified silica (column processes). The ability of the materials to remove 2,4-D, 2,4-DP, 2,4-DB and NAA herbicides is shown by representative examples given in Fig. 6 where the percentage of extraction $(\% E$ ) by the partially $\mathbf{G}(\mathrm{a})$ and fully substituted $\mathbf{H}$ (b) calix[4]arene amine silicas is plotted against the volume of aqueous solutions containing 2,4-D. This figure demonstrates that the extraction of this herbicide (the same pattern is found for the others) is around $100 \%$ before the saturation point is reached.

Recycling of the immobilised calix[4] arene amine materials. Having studied the extraction properties of the materials and demonstrated their efficiency to uptake acid herbicides from aqueous solutions at $298 \mathrm{~K}$, it was necessary to recycle the material with the aim to optimise their production costs and also to avoid the ecological disposal problems that used materials can carry. Subsequently the developed material could not only be re-used but the recycling process would allow for collection of the contaminants eluted from the material for proper disposal. A pH switching mechanism consisting of treating the materials with an aqueous solution of $\mathrm{NaOH}$ (1 mol $\mathrm{dm}^{-3}$ ) was used for the recycling process.

After recycling the materials, the capacity of the modified silica to extract acid herbicides was investigated. Two chlorinated acids were used for the extraction experiments $(2,4$ dichlorophenoxyacetic acid (2,4-D) and 4-(2,4-dichlorophenoxy) butyric acid (BU)). Fig. 7 shows the percentages of 2,4-
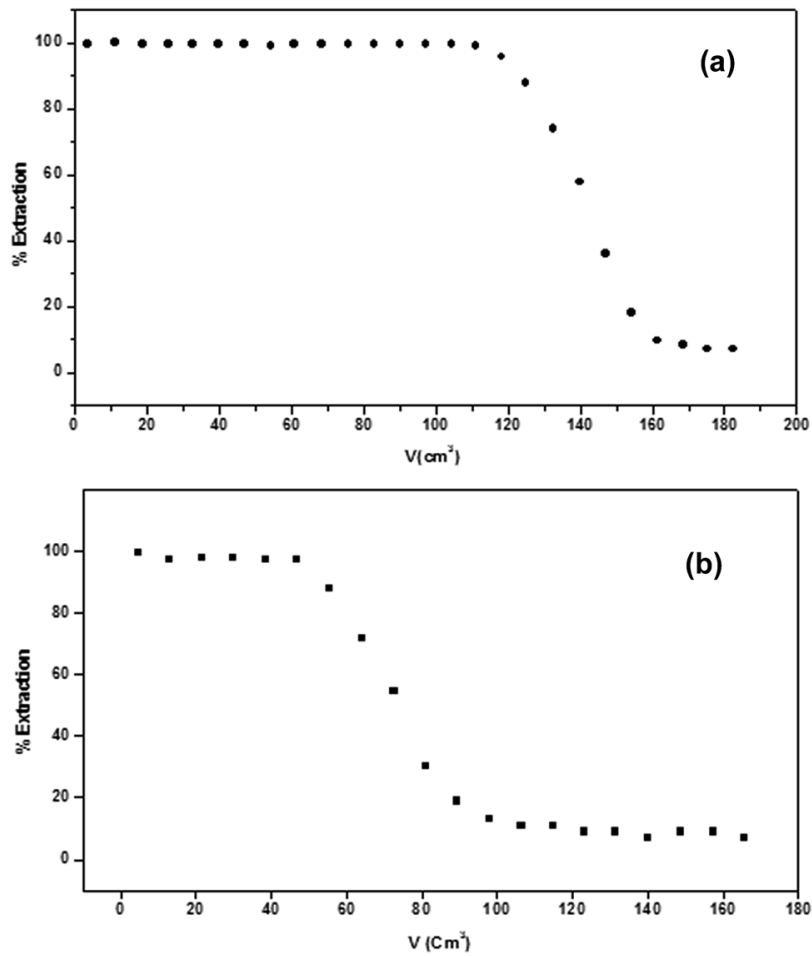

Fig. 6 Percentages of extraction of 2,4-D from water by $\mathrm{G}(\mathrm{a})$ and $\mathrm{H}$ (b). 

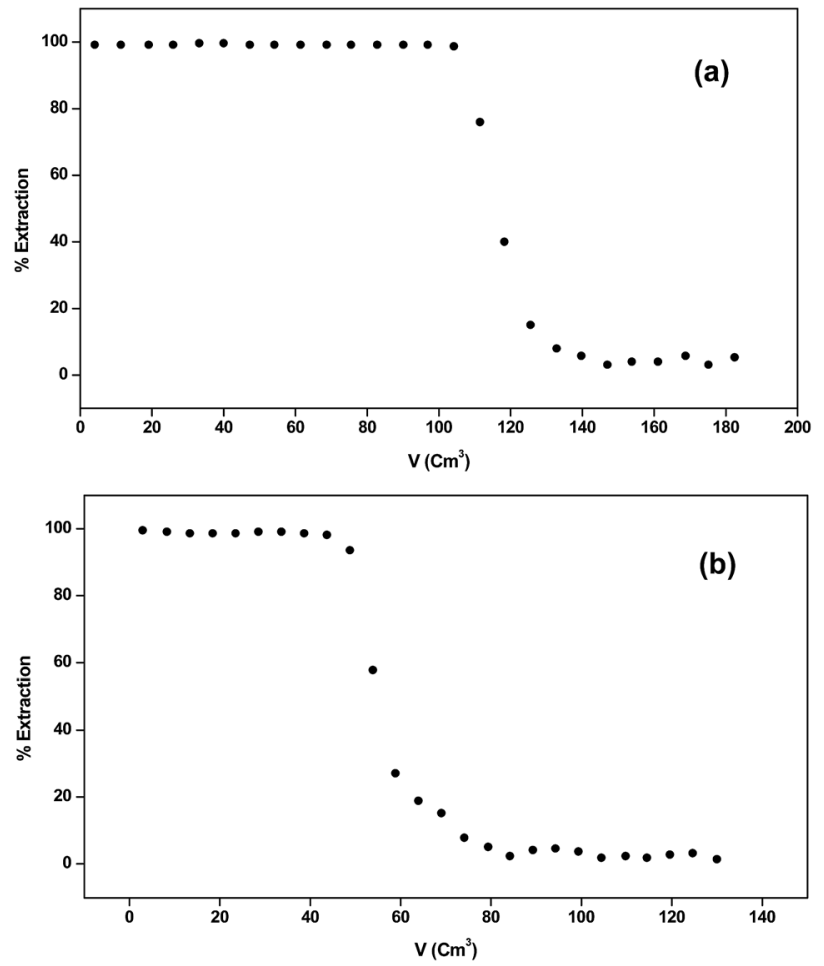

Fig. 7 Percentages of extraction of 2,4-D from water by $G(a)$ and $H$ (b) using the recycled materials.

dichlorophenoxyacetic acid (2,4-D) retained into the solid supporting partially $\mathbf{G}$ and fully $\mathbf{H}$ substituted calix[4]arene amine derivatives after the regeneration process at $298 \mathrm{~K}$.

The extraction capacity of the materials after the recycling process was calculated using the saturation point previously discussed. Table 5 reports the extraction capacity of the recycled partially and fully substituted calix[4]arene derivative anchored to silica, respectively. The concentrations of the acid herbicides (2,4-dichlorophenoxy and 4-(2,4-dichlorophenoxy)butyric acids) and the volume of the aqueous solution used to reach the saturation of the materials are also reported. It can be seen from these data that the capacity of the material was only slightly reduced by the regeneration process by $0.04-0.05 \mathrm{mmol} \mathrm{g}^{-1}$ (15.4-18.5\%) and $0.06-0.09 \mathrm{mmol} \mathrm{g}^{-1}(10.9-16.4 \%)$ for the partially and fully substituted calix[4]arene amino derivative, respectively, relative to the original capacity.

\section{Comparative studies}

The material currently used for the removal of herbicides from water is activated carbon, which unlike the ones reported in this paper (calix[4]arene amine modified silica, selective for the proton) lacks selectivity. In addition, organic matter present in water can block the pores of activated carbon and make this material unable to remove herbicides from water. ${ }^{34}$ Another important aspect to emphasise is that the regeneration of activated carbon requires a temperature of $950{ }^{\circ} \mathrm{C}$ in a steam air atmosphere while our materials can be easily recycled via a pH switching mechanism. ${ }^{35}$

Several hydrophilic polymeric sorbents (solid phase extraction cartridges) such as Strata-X (pyrrolidone anchored into a styrene skeleton), Oasis HLB (macroporous poly( $N$-vinyl pyrrolidone) DVB0 copolymer), SAX (strong anion exchanger), C18 (silica gel) and phenyl silica have been used for the removal of phenoxyacid herbicides from water. Among these the best extractants appears to be phenyl silica for 2,4-DB with an almost $100 \%$ of extraction when using deionised water samples $(10$ $\mathrm{cm}^{3}$ ) containing $5 \mu \mathrm{g}$ of these herbicides. ${ }^{36}$ A quantitative comparative evaluation of these materials as compared with the ones reported in this paper cannot be made due to the unavailability of capacity values (maximum amount of herbicide removed per $\mathrm{g}$ of material). However the performance of these hydrophilic sorbents was directly linked to their aromatic structure, which can interact with aromatic rings of chlorophenoxy acid herbicides via $\pi-\pi$ interactions. The interaction of calix[4]arene amine derivative anchored to silica with phenoxyacids via a proton transfer is much stronger than the $\pi-\pi$ interaction and therefore the latter are likely to be a more effective extracting agent for these pollutants than the former.

In our knowledge this is the first study in which Supramolecular Chemistry has been used to modify silica with the purpose of removing chlorophenoxy acids from water.

\section{Conclusions}

From the above discussion on the calix[4]arene amine derivatives, the following major conclusions can be drawn.

(i) ${ }^{1} \mathrm{H}$-NMR studies on the interaction of 5,11,17,23-tetra-tertbutyl 25,27-bis(ethylamine)ethoxy 26,28-dihydroxy calix[4]arene with several acid herbicides revealed a direct correlation between the conformational changes of the receptor and the $\mathrm{p} K_{\mathrm{a}}$ values of the phenoxy acids.

Table 5 Extraction capacity ( $\mathrm{mmol} \mathrm{g}{ }^{-1}$ of material) of the partially substituted and fully substituted calix[4]arene derivative anchored silica after the regeneration process form aqueous solution at $298 \mathrm{~K}$

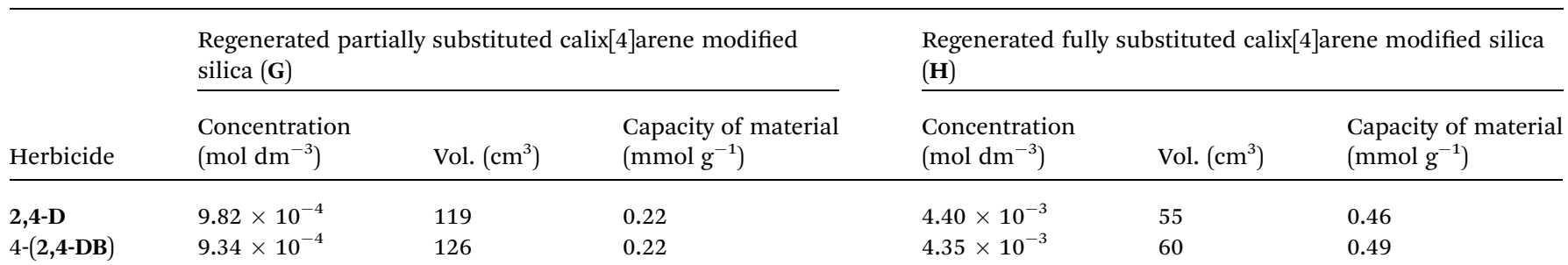


(ii) Two units of herbicides are taken up per unit of receptor as a result of a proton transfer reaction from the herbicide to the receptor. The complex composition is also confirmed by X-ray diffraction studies.

(iii) Two new recyclable materials based on silica gel modified with amino silane were prepared and characterised by elemental analysis and by acid-base back titrations in order to calculate the content of amine groups per gram of material. These materials were used to uptake several acid herbicides from aqueous solutions at $298 \mathrm{~K}$. These experiments show that the capacity of the fully substituted calix[4]arene amino modified silica to extract these herbicides is approximately higher by a factor of two than that of the partially substituted calix[4]arene based silica. These findings demonstrate that fundamental studies provide the most insightful path for the application of these receptors in the removal of herbicides from water.

(iv) Titration calorimetry provides a quick and efficient tool to determine the conditions (mass : solution ratio, temperature and kinetics of the process) for optimal removal of these pollutants from water.

(v) A pH switching mechanism consisting of treating the extracting materials with an aqueous solution of $\mathrm{NaOH}(1 \mathrm{~mol}$ $\mathrm{dm}^{-3}$ ) was used to recycle the materials. After several recycling processes, the extraction capacity toward 2,4-D and BU herbicides was observed to remain to a level of $80-90 \%$ of its original value.

Further experimental work using real water samples from contaminated sources is now in progress.

\section{Experimental section}

\section{Chemicals}

2,4-Dichlrophenoxyacetic acid, 2,4-D, 98\%; 2,4,5-trichlorophenoxyacetic acid, 2,4,5-T, 97\%; 2-(2,4-dichlorophenoxy)propionic acid, 2,4-DP, 95\%; 2-(2,4,5-trichlorophenoxy propionic acid, 2-2,4,5-T; 4-(2,4-dichlorophenoxy)butyric acid, BU, 95\%; 1-naphthalene acetic acid, NAA, 98\%, were purchased from Aldrich. 2,3,6-Trichlorophenylacetic acid, 2,3,6-T, 97\%, was purchased from Lancaster.

Synthesis of $1(5,11,17,23$-tetratert-butyl $25,27-$ bis(diethylamino(ethoxy-26,28-dihydroxy calix[4]arene)))

A solution of $p$-tert-butyl calix[4]arene (2.09 g, $3.22 \mathrm{mmol})$, potassium carbonate $(2.67 \mathrm{~g}, 19.34 \mathrm{mmol})$ and 18-crown-6 (0.26 $\mathrm{g}, 0.97 \mathrm{mmol})$ was prepared in acetonitrile $\left(150 \mathrm{~cm}^{3}\right)$ under an inert atmosphere. The resulting solution was stirred at $25{ }^{\circ} \mathrm{C}$ for 30 minutes. Then 2-diethylaminoethylchloride hydrochloride $(2.22 \mathrm{~g}, 12.89 \mathrm{mmol})$ was added and the resulting mixture was stirred at $80{ }^{\circ} \mathrm{C}$ for $6 \mathrm{~h}$. The progress of the reaction was monitored by TLC using a dichloromethane : methanol $(9: 1, \mathrm{v} / \mathrm{v})$ mixture. Once the reaction was completed, the mixture was allowed to cool to RT before the acetonitrile was removed in vacuo. The resulting crude mixture was extracted with dichloromethane $\left(100 \mathrm{~cm}^{3}\right)$ and washed with water $\left(100 \mathrm{~cm}^{3}\right)$. The organic phase was separated and dried over magnesium sulphate before being concentrated in vacuo to furnish a residue (brown solid). The desired product was re-crystallised from the residue using methanol, thus affording white crystals $(2.64 \mathrm{~g}$, $60 \%$ yield).

${ }^{1} \mathrm{H} \mathrm{NMR}\left(\mathrm{CDCl}_{3}, 300 \mathrm{MHz}\right) \delta(\mathrm{ppm}) J(\mathrm{~Hz}) ; 7.21$ (s, 2H, Ar-OH), 7.05 (s, 4H, Ar-H), 6.76 (s, 4H, Ar-H), 4.33 (d, 4H, J = 12.91, Ar$\mathrm{CH}_{2}-\mathrm{Ar}$ ), 4.03 (m, 4H, Ar-O- $\mathrm{CH}_{2}$ ), 3.29 (d, 4H, $J=12.91, \mathrm{Ar}^{-} \mathrm{CH}_{2}-$ $\mathrm{Ar}), 3.08\left(\mathrm{t}, 4 \mathrm{H}, \mathrm{Ar}-\mathrm{O}-\mathrm{CH}_{2}-\mathrm{CH}_{2}-\mathrm{N}\right), 2.69\left(\mathrm{~m}, 8 \mathrm{H}, \mathrm{CH}_{2}-\right.$ $\left.\mathrm{N}\left(\mathrm{CH}_{2} \mathrm{CH}_{3}\right)_{2}\right), 1.29\left(\mathrm{~s}, \quad 18 \mathrm{H}, \quad \mathrm{C}-\left(\mathrm{CH}_{3}\right)_{3}\right), 1.10 \quad(\mathrm{~m}, \quad 12 \mathrm{H},-$ $\left.\mathrm{N}\left(\mathrm{CH}_{2} \mathrm{CH}_{3}\right)_{2}\right), 0.94\left(\mathrm{~s}, 18 \mathrm{H}, \mathrm{C}-\left(\mathrm{CH}_{3}\right)_{3}\right)$.

Elemental analysis was carried out in duplicate at the University of Surrey and the results found were in reasonable agreement with the calculated, values as shown below:

Calculated\%: $\mathrm{C}=77.14, \mathrm{H}=8.09, \mathrm{~N}=4.50$.

Found $\%$ : $\mathrm{C}=77.00, \mathrm{H}=8.01, \mathrm{~N}=4.37$.

Receptor 2 (5,11,17,23-tetra-tert-butyl 25,26,27,28(diethyllamino)ethoxy calix[4]arene)

Receptor 2 (5,11,17,23-tetra-tert-butyl 25,26,27,28-(diethyllamino)ethoxy calix[4]arene) was synthesised and characterised by ${ }^{1} \mathrm{H}$ NMR and microanalysis as previously described. ${ }^{31}$

${ }^{\mathbf{1}} \mathbf{H}$-NMR measurements. ${ }^{1} \mathrm{H}$-NMR measurements were recorded at $298 \mathrm{~K}$ using a Bruker AC-300 E pulsed Fourier transform NMR spectrometer. Typical operating conditions for routine proton measurements involved "pulse" or flip angle of 300 , spectral frequency (SF) of $300.135 \mathrm{MHz}$, delay time of 1.69 $\mathrm{s}$, acquisition time (AQ) of $1.819 \mathrm{~s}$ and line broadening of 0.55 Hz. Solutions of the samples in question $\left(9 \times 10^{-4}-5 \times 10^{-3}\right.$ $\mathrm{mol} \mathrm{dm}{ }^{-3}, \sim 0.5 \mathrm{ml}$ ) were prepared in $\mathrm{CD}_{3} \mathrm{CN}$ and placed in 5 mm NMR tubes using TMS as the internal reference. The interaction of the ligand [(5,11,17,23-tetra-tert-butyl 25,27-bis(diethylamino)ethoxy-26,28-dihydroxy calix[4]arene)] towards acid herbicides was studied in solution using the ${ }^{1} \mathrm{H}-\mathrm{NMR}$ technique. These measurements were carried out by adding different concentrations of the acid herbicide $\left(3-5 \times 10^{-2} \mathrm{~mol}\right.$ $\mathrm{dm}^{-3}$ ) into the NMR tube containing a known amount of the ligand $\left(0.5 \mathrm{ml}, 2-4 \times 10^{-2} \mathrm{~mol} \mathrm{dm}^{-3}\right)$ dissolved in $\mathrm{CD}_{3} \mathrm{CN}$ or $\mathrm{CD}_{3} \mathrm{OD}$ at $298 \mathrm{~K}$. Stepwise additions of varying amounts of the acid herbicide were made until changes in chemical shifts ceased. Proton chemical shifts of the free and the complex ligand were measured.

Conductance measurements. For these measurements, a Wayne-Kerr Autobalance Universal Bridge, type B642, was used.

For the conductometric titrations, fresh solutions of the appropriate acid herbicide and the receptors were prepared in acetonitrile and methanol for each experimental run. The conductometric cell was filled with a known amount of the acid herbicide or ligand (approx. $25 \mathrm{ml}$ ) in methanol or acetonitrile. Then the electrodes were inserted into the cell. The closed system was placed in a thermostat bath at $298.15 \mathrm{~K}$ to achieve thermal equilibrium. Accurate aliquots of the ligand or acid herbicide were added respectively into the cell using a hypodermic syringe. After equilibrium was achieved, the conductivity was measured.

$\mathrm{X}$-ray diffraction data. The measurements were performed at low temperature on an Enraf-Nonius Kappa-CCD diffractometer 
with graphite-monochromated $\operatorname{MoK} \alpha(\lambda=0.71073 \AA)$ radiation. Diffraction data were collected ( $\varphi$ and $\omega$ scans with $\kappa$-offsets) with COLLECT. ${ }^{37}$ Integration and scaling of the reflections was performed with HKL DENZO-SCALEPACK ${ }^{38}$ suite of programs. The unit cell parameters were obtained by least-squares refinement based on the angular settings for all collected reflections using HKL SCALEPACK. The data were corrected by Lorentz effect but not for absorption as the linear absorption coefficient times the largest crystal size was less than 0.053 . The structure was solved by direct methods with SHELXS- $97^{39}$ and the molecular model refined by full-matrix least-squares procedure with SHELXL-97.90 One tert-butyl group on the upper rim showed rotational disorder that could be modelled in terms of two split positions with unequal occupancies. They were refined with $\mathrm{C}-\mathrm{C}$ bond lengths and $\mathrm{C} \cdots \mathrm{C}$ distances constrained to target values of 1.53(2) and 2.49(2) $\AA$, respectively and with their occupancies summing up to one. Several H-atoms, including the ones on the calixarene pendant amine and hydroxyl groups and the water molecule were located at approximate positions in a difference Fourier map phased on the heavier atoms. However, all hydrogen atoms but the ones of the water molecule were positioned stereo-chemically and refined with the riding model. The methyl hydrogen atoms locations were optimised during the refinement by treating them as rigid bodies which were allowed to rotate around the corresponding $\mathrm{C}-\mathrm{CH}_{3}$ bond such as to maximise the residual electron density at their calculated positions. A similar procedure was employed to refine the orientation of the hydroxyl $\mathrm{O}-\mathrm{H}$ groups on the calixarene lower bore. The water $\mathrm{H}$-atoms were refined at their found positions with $\mathrm{O}-\mathrm{H}$ and $\mathrm{H} \cdots \mathrm{H}$ distances constrained to target values of 0.86(1) and 1.36(1) A. Crystal data and refinement results are summarised in Table 1. For further information see ESI. $\dagger$

\section{Attachment of receptors to the solid support synthesis of 25,26,27,28-tetrahydroxycalix[4]arene, B (Scheme 1)}

The synthesis of 25,26,27,28-tetrahydroxycalix[4]arene (Scheme 1, B) was carried out by de-tert-butylation of $p$-tert-butylcalix[4]arene (Scheme 1, A) following the procedure reported in the literature. ${ }^{41,42}$

${ }^{1} \mathrm{H}$ NMR $\left(\mathrm{CDCl}_{3} ; 300 \mathrm{MHz}\right) \delta 10.22(\mathrm{~s}, 4 \mathrm{H}, \mathrm{OH}), 7.07(\mathrm{~d}, 8 \mathrm{H}$, $J=7.50, \mathrm{Ar}-\mathrm{H}), 6.75$ (t, $4 \mathrm{H}, J=7.20, \mathrm{Ar}-\mathrm{H}), 4,27$ (br, $4 \mathrm{H}, \mathrm{Ar}^{-} \mathrm{CH}_{2}-$ $\mathrm{Ar}$ ), 3.57 (br, $\left.4 \mathrm{H}, \mathrm{Ar}-\mathrm{CH}_{2}-\mathrm{Ar}\right) \mathrm{OH}_{4}$.

Elemental analysis was carried out in duplicate at the University of Surrey and the found results were in reasonable agreement with the calculated values as shown below.

Calculated\%: $\mathrm{C}=79.23, \mathrm{H}=5.70$.

Found\%: $\mathrm{C}=79.08, \mathrm{H}=5.62$.

Synthesis of 25,27-dihydroxy-26,28-(diethylamine)ethoxy calix [4] arene, C (Scheme 1)

A solution of $\mathbf{B}(3.0 \mathrm{~g}, 7.08 \mathrm{mmol})$, potassium carbonate $(4.9 \mathrm{~g}$, $35.0 \mathrm{mmol})$ and 18-crown-6-ether (0.46 g, $1.75 \mathrm{mmol})$ was prepared in acetonitrile $\left(150 \mathrm{~cm}^{3}\right)$ under an inert atmosphere. The resulting solution was stirred at $25{ }^{\circ} \mathrm{C}$ for 30 minutes. Then 2-diethylaminoethylchloride hydrochloride $(6.09 \mathrm{~g}, 35.4 \mathrm{mmol})$ was added. The resulting mixture was stirred at $80{ }^{\circ} \mathrm{C}$ for $6 \mathrm{~h}$. The progress of the reaction was monitored by TLC [dichloromethane : methanol $(9: 1, \mathrm{v} / \mathrm{v})]$. Once the reaction was completed, the mixture was allowed to cool to RT, then the acetonitrile was removed in vacuo. The resulting crude mixture was extracted into dichloromethane $\left(100 \mathrm{~cm}^{3}\right)$ and washed with water $\left(100 \mathrm{~cm}^{3}\right)$. The organic phase was separated and dried over magnesium sulphate before being concentrated in vacuo to furnish a residue (brown solid). The desired product was recrystallised from the residue using methanol, thus affording white crystals ( $2.64 \mathrm{~g}, 60 \%$ yield).

${ }^{1} \mathrm{H}$ NMR $\left(\mathrm{CDCl}_{3}, 300 \mathrm{MHz}\right) \delta 7.81(\mathrm{~s}, 1 \mathrm{H},-\mathrm{OH}), 7.06(\mathrm{~d}, 2 \mathrm{H}$, $J=7.8, \mathrm{Ar}-\mathrm{H}), 6.87$ (d, $2 \mathrm{H}, J=8.10, \mathrm{Ar}-\mathrm{H}), 6.68(\mathrm{~m}, 2 \mathrm{H}, \mathrm{Ar}-\mathrm{H})$, 4.38 (d, 2H, $J=12.91$, Ar- $\mathrm{CH}_{2}-\mathrm{Ar}$ ), 4.05 (t, 2H, $J=6.90$, Ar-O$\mathrm{CH}_{2}$ ), 3.37 (d, $2 \mathrm{H}, J=12.91, \mathrm{Ar}_{-} \mathrm{CH}_{2}-\mathrm{Ar}$ ), $3.10(\mathrm{t}, 2 \mathrm{H}, J=7.05$, $\left.\mathrm{CH}_{2}-\mathrm{N}\left(\mathrm{CH}_{2} \mathrm{CH}_{3}\right)_{2}\right), 2.70\left(\mathrm{q}, 4 \mathrm{H}, J=6.77,-\mathrm{N}\left(\mathrm{CH}_{2} \mathrm{CH}_{3}\right)_{2}\right), 1.12(\mathrm{t}$, $\left.6 \mathrm{H}, J=7.20,-\mathrm{N}\left(\mathrm{CH}_{2} \mathrm{CH}_{3}\right)_{2}\right)$.

Elemental analysis was carried out in duplicate at the University of Surrey and the results found were in reasonable agreement with the calculated values as shown below.

Calculated\%: $\mathrm{C}=77.14, \mathrm{H}=8.09, \mathrm{~N}=4.50$.

Found $\%$ : $\mathrm{C}=77.00, \mathrm{H}=8.01, \mathrm{~N}=4.37$.

Synthesis of 25,26,27,28-(diethyllamino)ethoxy calix[4]arene, D (Scheme 1)

A solution of $\mathbf{B}(2.52 \mathrm{~g}, 5.52 \mathrm{mmol})$ and sodium hydride $(2.12 \mathrm{~g}$, $88.36 \mathrm{mmol})$ was prepared in $150 \mathrm{ml}$ of THF : DMF $(8: 2, \mathrm{v} / \mathrm{v})$ solvent system under an inert atmosphere. The resulting solution was stirred at $25{ }^{\circ} \mathrm{C}$ for 30 minutes. Then 2-diethylaminoethylchloride hydrochloric $(6.09 \mathrm{~g}, 35.4 \mathrm{mmol})$ was added, following the procedure described by Danil de Namor and co-workers ${ }^{\mathbf{3 1}}$ and the precipitation of white crystals was observed (1.01 g, 40\% yield).

${ }^{1} \mathrm{H}$ NMR $\left(\mathrm{CDCl}_{3}, 300 \mathrm{MHz}\right) \delta \mathrm{ppm} 6.59(\mathrm{~m}, 12 \mathrm{H}, \mathrm{Ar}-\mathrm{H}), 4.40$ (d, $4 \mathrm{H}, J=12.91$, Ar-CH $-\mathrm{Ar}$ ), 4.03 (t, 8H, Ar-O- $\mathrm{CH}_{2}$ ), 3.17 (d, $4 \mathrm{H}$, $\left.J=12.01, \mathrm{Ar}^{-} \mathrm{CH}_{2}-\mathrm{Ar}\right), 2.97\left(\mathrm{t}, 8 \mathrm{H}, \mathrm{CH}_{2}-\mathrm{N}\left(\mathrm{CH}_{2} \mathrm{CH}_{3}\right)_{2}\right), 2.60(\mathrm{~m}$, $\left.16 \mathrm{H},-\mathrm{N}\left(\mathrm{CH}_{2} \mathrm{CH}_{3}\right)_{2}\right), 1.04$ (t, 24H, $\left.-\left(\mathrm{CH}_{2} \mathrm{CH}_{3}\right)_{2}\right)$.

Elemental analysis was carried out in duplicate at the University of Surrey and the results found were in reasonable agreement with the calculated values as shown below.

Calculated\%: $\mathrm{C}=76.06, \mathrm{H}=9.33, \mathrm{~N}=6.82$.

Found $\%$ : $\mathrm{C}=76.10, \mathrm{H}=9.34, \mathrm{~N}=6.84$.

Synthesis of 5,17-dialdehyde-25,27-dihydroxy-26,28-(diethyl amine)ethoxy calix[4]arene, $\mathrm{E}$ (Scheme 1)

A solution of $\mathbf{C}(0.9 \mathrm{~g}, 2.12 \mathrm{mmol})$ in dichloromethane $\left(70 \mathrm{~cm}^{3}\right)$ was cooled to $-10{ }^{\circ} \mathrm{C}$. Then, $\alpha, \alpha$-dichloromethyl methyl ether $\left(3.0 \mathrm{~cm}^{3}, 32 \mathrm{mmol}\right)$ and tin(Iv) chloride $\left(32 \mathrm{~cm}^{3}, 32 \mathrm{mmol}\right)$ were added following the procedure detailed in the literature. ${ }^{\mathbf{4 3}}$ Yellow crystals $(0.50 \mathrm{~g}, 53 \%$ yield) were obtained.

${ }^{1} \mathrm{H}$ NMR $\left(\mathrm{CDCl}_{3}, 300 \mathrm{MHz}\right) \delta \mathrm{ppm} 9.80$ (s, 2H, Ar-CHO), 8.87 (s, 2H, Ar-OH), 7.64 (s, 4H, Ar-H), 6.92 (d, 4H, $J=8.10, \operatorname{Ar}-\mathrm{H})$,

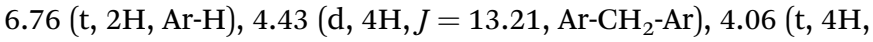
Ar-O- $\mathrm{CH}_{2}$ ), 3.48 (d, 4H, J = 13.21, Ar- $\mathrm{CH}_{2}-\mathrm{Ar}$ ), 3.05 (t, 4H, $\mathrm{CH}_{2}-$ $\left.\mathrm{N}\left(\mathrm{CH}_{2} \mathrm{CH}_{3}\right)_{2}\right), 2.69\left(\mathrm{q}, 8 \mathrm{H},-\mathrm{N}\left(\mathrm{CH}_{2} \mathrm{CH}_{3}\right)_{2}\right), 1.11(\mathrm{t}, 12 \mathrm{H}$, $\left.-\mathrm{N}\left(\mathrm{CH}_{2} \mathrm{CH}_{3}\right)_{2}\right)$. 
Elemental analysis was carried out in duplicate at the University of Surrey and the results found were in good agreement with the calculated values as shown below.

Calculated\%: $\mathrm{C}=74.31, \mathrm{H}=7.42, \mathrm{~N}=4.13$.

Found $\%$ : $\mathrm{C}=74.89, \mathrm{H}=7.08, \mathrm{~N}=4.07$.

\section{Synthesis of 1-formaldehyde-25,26,27,28-(diethylamino) ethoxy calix[4]arene, F (Scheme 1)}

A solution of $\alpha, \alpha$-dichloromethyl methyl ether $\left(3.0 \mathrm{~cm}^{3}, 32\right.$ $\mathrm{mmol}$ ) and tin(Iv) chloride $\left(32 \mathrm{~cm}^{3}, 32 \mathrm{mmol}\right)$ in dichloromethane $\left(70 \mathrm{~cm}^{3}\right)$ was cooled down to $-10{ }^{\circ} \mathrm{C}$. Then $\mathbf{D}(1.1 \mathrm{~g}$, $1.29 \mathrm{mmol}$ ) was introduced, following the procedure reported in the literature. ${ }^{44}$ The yellow solid was re-crystallised from acetonitrile, furnishing yellow crystals ( $0.5 \mathrm{~g}, 45 \%$ yield).

${ }^{1} \mathrm{H} \mathrm{NMR}\left(\mathrm{CDCl}_{3}, 300 \mathrm{MHz}\right) \delta \mathrm{ppm} 9.48(\mathrm{~s}, 1 \mathrm{H},-\mathrm{CHO}), 6.93(\mathrm{~s}$, $2 \mathrm{H}, \mathrm{Ar}-\mathrm{H}), 6.65$ (m, 4H, Ar-H), 6.44 (m, 3H, Ar-H), $6.34(\mathrm{~m}, 2 \mathrm{H}$, $\mathrm{Ar}-\mathrm{H}$ ), 4.38 (d, $\left.4 \mathrm{H}, J=12.01, \mathrm{Ar}-\mathrm{CH}_{2}-\mathrm{Ar}\right), 4.33$ (d, $4 \mathrm{H}, J=12.01$, Ar- $\mathrm{CH}_{2}-\mathrm{Ar}$ ), 3.94 (m, 8H, Ar-O- $\mathrm{CH}_{2}$ ), 3.18 (d, $4 \mathrm{H}, J=12.01$, Ar-

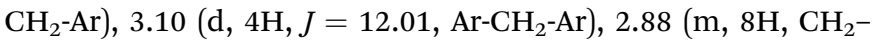
$\left.\mathrm{N}\left(\mathrm{CH}_{2} \mathrm{CH}_{3}\right)_{2}\right), 2.53\left(\mathrm{~m}, 16 \mathrm{H},-\mathrm{N}\left(\mathrm{CH}_{2}-\mathrm{CH}_{3}\right)_{2}\right), 0.97(\mathrm{~m}, 24 \mathrm{H}$, $\left.-\mathrm{N}\left(\mathrm{CH}_{2} \mathrm{CH}_{3}\right)_{2}\right)$.

Microanalysis data are as follows:

Calculated\%: $\mathrm{C}=74.96, \mathrm{H}=9.02, \mathrm{~N}=6.60$.

Found $\%$ : $\mathrm{C}=75.48, \mathrm{H}=9.34, \mathrm{~N}=6.84$.

\section{Synthesis of 3-aminopropyldimethylsilylane silica, J (Scheme 1)}

Dried silica (Scheme 1, I) (10 g) was dispersed in anhydrous toluene $\left(150 \mathrm{~cm}^{3}\right)$. To the resulting slurry, 3-aminopropyltrimethylsilane $(4.9 \mathrm{~g}, 42.6 \mathrm{mmol})$ was added. The resulting mixture was refluxed for $6 \mathrm{~h}$ and then cooled to $25{ }^{\circ} \mathrm{C}$, filtered and washed first with toluene and then with methanol. ${ }^{45,46}$

Elemental analysis for $\mathbf{J}$ was performed and the results were as follows:

Calculated\%: $\mathrm{C}=3.47, \mathrm{H}=0.81, \mathrm{~N}=0.82$.

Found\%: $\mathrm{C}=3.36, \mathrm{H}=0.75, \mathrm{~N}=1.00$.

Synthesis of the solid supported partially and fully functionalised calix[4] arene amino derivatives, $\mathbf{G}$ and $\mathbf{H}$

A dispersion of anhydrous 3-aminopropyldimethylsilylated silica $(1 \mathrm{~g}, 0.75 \mathrm{mmol})$ in absolute methanol $\left(50 \mathrm{~cm}^{3}\right)$ was prepared. To the resulting slurry, $5 \mathrm{M}$ methanolic solution of $\mathrm{HCl}\left(0.15 \mathrm{~cm}^{3}, 0.25 \mathrm{mmol}\right)$ was added. This was followed by 1,13-formaldehyde-25,27-dihydroxy-26,28-(diethylamino)ethoxy calix[4]-arene $(0.65 \mathrm{~g}, 0.96 \mathrm{mmol})$ to obtain $\mathbf{G}$ or 1 -formaldehyde-25,26,27,28-(diethylamino)ethoxy calix[4]arene $(0.40 \mathrm{~g}$, $0.47 \mathrm{mmol}$ ) to obtain $\mathbf{H}^{.4-49}$ The resulting mixture was stirred at $25{ }^{\circ} \mathrm{C}$ for $72 \mathrm{~h}$. Concentrated $\mathrm{HCl}$ was added to the slurry until the $\mathrm{pH}$ was lower than 2 . The acidified slurry was filtered out and the resulting solid was washed with dichloromethane (50 $\left.\mathrm{cm}^{3}\right)$, methanol $\left(50 \mathrm{~cm}^{3}\right)$, aqueous $\mathrm{NaOH}\left(50 \mathrm{~cm}^{3}\right)$ and water $(50$ $\mathrm{cm}^{3}$ ) before being dried over $\mathrm{CaCl}_{2}$ in vacuo for $12 \mathrm{~h}$.

Elemental analysis was carried out: G, calculated\%: $\mathrm{C}=$ 20.58, $\mathrm{H}=2.57, \mathrm{~N}=1.85$; found $\%$ : $\mathrm{C}=20.54, \mathrm{H}=2.66, \mathrm{~N}=$ $1.80 ; \mathrm{H}$, calculated $\% \mathrm{C}=18.07, \mathrm{H}=2.34, \mathrm{~N}=1.81$, found $\% \mathrm{C}=$ 17.93, $\mathrm{H}=2.38, \mathrm{~N}=1.92$.

\section{FTIR characterisation}

Infrared spectroscopy was used in order to identify in a first stage the immobilisation of (3-aminopropyl)trimethoxysilane (APTMS) and in a second stage the amino calix[4]arene organic moieties onto the surface of silica $\mathbf{H}$ and $\mathbf{G}$. From the FT-IR pattern of the parent silica gel, silica gel modified with aminosilane and silica modified with amino calix[4]arene hybridized silicas.

\section{Extraction experiments}

These were carried out in batch ( $\mathrm{pH}$ effect, capacity of the material) and titration calorimetry (to assess the kinetics, optimal solid/solution ratio and temperature) and in column (\% of extraction, recycling of the material).

\section{Effect of $\mathrm{pH}$ on the removal of herbicides from water}

The $\mathrm{pH}$ effect on the percentage of 2,4-D herbicide removed from aqueous solution by silica $\mathbf{H}$ was studied as a model for other herbicides. It was studied by adding $10 \mathrm{~cm}^{3}$ of known concentrations of 2,4-D herbicide $\left(1 \times 10^{-3} \mathrm{~mol} \mathrm{dm}^{-3}\right)$ to test tubes containing a fixed amount of the silica material, $\mathbf{H}$. After equilibrium was obtained the solutions were filtered on a 0.45 $\mu \mathrm{m}$ (pore size) membrane filter using a syringe. The initial and equilibrium concentrations of the herbicide were measured spectrophotometrically. The stock solutions of pollutants were adjusted with hydrochloric acid $(\mathrm{HCl})$ or ammonium hydroxide $\left(\mathrm{NH}_{4} \mathrm{OH}\right)$ to the desired $\mathrm{pH}$ values ranging from 1 to 10 . The $\mathrm{pH}$ measurements were carried out with a HANNA ( $\mathrm{pH}$ 213) potentiometer equipped with a glass electrode. The electrode was calibrated with two reference solutions at $\mathrm{pH} 7$ and 4 .

\section{Determination of the capacity of the materials ( $G$ and $H$ ) to remove herbicides}

The removal capacity of the materials ( $\mathbf{G}$ and $\mathbf{H}$ ) towards herbicides was determined by using a batch procedure. Thus quantitative amounts of $\mathbf{G}$ or $\mathbf{H}(0.5 \mathrm{~g})$ were equilibrated with aqueous solutions containing different concentrations of the appropriate herbicide. The mixtures were left overnight in a thermostat controlled bath at $298.15 \mathrm{~K}$. Aliquots of the initial and equilibrium solutions were taken and analysed by UV spectrometry (Cecil 8000 UV-visible spectrophotometer). The same experiments were carried out using the 3-aminopropyldimethylsilylane silica, J.

\section{Calorimetric measurements}

These measurements were carried out in the Tronac 450 titration calorimeter which operates as an isoperibol calorimeter originally designed by Christensen and Izatt. ${ }^{\mathbf{5 0}}$

To check the reliability of the instrument the standard enthalpy of solution of THAM in an aqueous solution was determined. ${ }^{51}$ The value of $-29.8 \pm 0.3 \mathrm{~kJ} \mathrm{~mol}^{-1}$ was in good agreement with that reported in the literature. ${ }^{51}$ To this purpose, ampoules containing a known mass of dry solid material in a known volume of water at $298.15 \mathrm{~K}$ were broken in the calorimeter vessel. Heat of immersion of the unmodified 


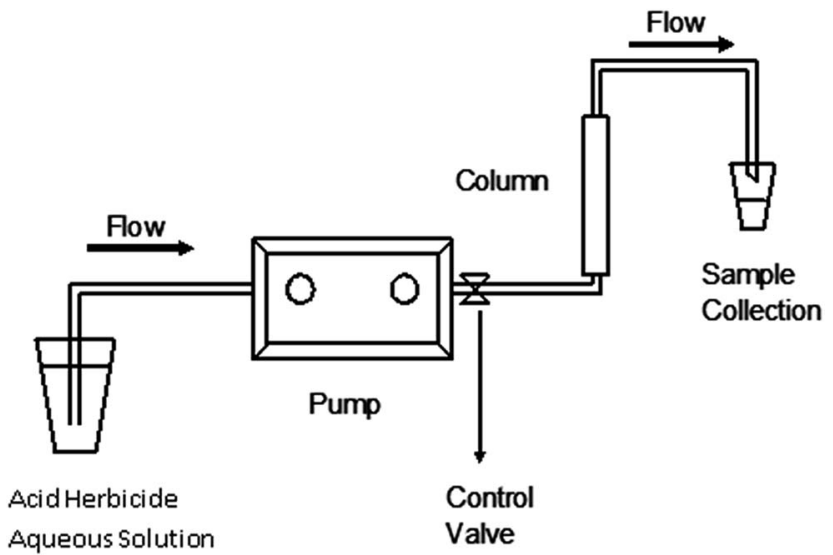

Fig. 8 Diagram of the apparatus for the pump-flow column extraction.

silica in water and in the presence of the herbicide and modified silica (partially substituted calix[4]arene anchored silica) were determined at $298.15 \mathrm{~K}$.

\section{Column extraction experiments}

To perform extraction experiments, small chromatographic columns were filled with the modified silica (containing the calixarene derivative, $\mathbf{G}$ and $\mathbf{H}$ ) and a mechanical pump was used to inject the acid herbicide solution into the column. The initial and the remaining concentrations of the acid herbicide in aqueous solution after passing through the column were measured by UV-visible spectrophotometry. All extraction experiments were performed at least twice (Fig. 8).

\section{Acknowledgements}

The authors thank the European Commission for the financial support provided under Contract ICA-CT-2000-10008 and the Leverhulme Trust for providing financial support to complete this work. The crystallographic work was supported by FAPESP of Brazil. O.E.P is a research fellow of CONICET, Argentina. This work is part of the Ph D theses of J.Z. and J.A.V, University of Surrey, 2006 and 2005 respectively.

\section{References}

1 D. H. Garabrant and M. A. Philbert, Crit. Rev. Toxicol., 2002, 32(4), 233.

2 S. M. Bradberry, A. T. Proudfoot and J. A. Vale, Toxicol. Rev., 2004, 23(2), 65.

3 J. M. Romero, N. L. Jorge and E. A. Castro, Int. J. Res. Chem. Environ., 2012, 2, 54 and ref. within.

4 S. Cho, S. Park, J. Kim Seung and Y. Kim Tae, Korean J. Chem. Eng., 2006, 23(4), 638.

5 E. Argesse, C. Bettiol, D. Marchetto, S. De Vetton, A. Zambon, P. Miana and P. F. Ghetti, Toxicol. in Vitro, 2005, 19, 1035.
6 M. S. Rodriguez Cruz, J. Baelum, L. J. Shaw, S. R. Sorensen, S. Shi, T. Aspray, C. S. Jacobsen and G. D. Bending, Soil Biol. Biochem., 2010, 42, 32 and refs therein.

7 D. Saraydin and E. Karadag, Iran. Polym. J., 1996, 5, 133-138.

8 J. B. Alam, A. K. Dikshit and M. Bandyopadhyay, Global NEST J., 2000, 2, 139.

9 J. Li, Y. Li and J. Lu, Appl. Clay Sci., 2009, 46, 314-318.

10 A. Legrouri, M. Lakraimi, A. De Roy and J. P. Besse, Water Res., 2005, 39, 3441.

11 K. Ignatowicz-Owsieniuk and I. Skoczko, Pol. J. Environ. Stud., 2002, 11, 339.

12 B. H. Hameed, J. M. Salman and A. L. Ahmad, J. Hazard. Mater., 2009, 163, 121.

13 J. M. Salman and B. H. Hameed, Desalination, 2010, 256, 129. 14 O. O. Nalcaci, N. Boke and B. Ovez, J. Environ. Eng., 2011, 137, 1136.

15 F. Danil de Namor, R. M. Cleverley and M. L. ZapataOrmachea, Chem. Rev., 1998, 98, 2495.

16 J.-M. Lehn, Supramolecular Chemistry, Wiley-VCH, 1995.

17 J. W. Steed, D. P. Turner and K. J. Wallace, Core Concepts in Supramolecular Chemistry and Nanochemistry, John Wiley \& Sons, 2007.

18 P. J. Cragg, Supramplecular Chemistry: From Biological Inspiration to Biomedical Applications, Springer, 2010.

19 C. D. Gutsche, Calixarenes. An Introduction, Royal Society of Chemistry, 2008.

20 Calixarenes 2001, ed. M. Z. Asfari, V. Böhmer, J. Harrowfield and J. Vicens, Springer, 2001.

21 C. D. Gutsche, Calixarenes Revisited, Royal Society of Chemistry, Cambridge, UK, 1998.

22 J. Vicens and J. Harrowfield, Calixarenes in the Nanoworld, Springer, 2007.

23 J. Vicens, Z. Asfari and J. M. Harrowfield, Calixarenes 50th Anniversary: Commemorative Volume, Kluwer Academic Publishers, 1994.

24 L. O. Healy, M. M. McEnery, D. G. McCarthy, S. J. Harris and J. D. Glennon, Anal. Lett., 1998, 31(9), 1543.

25 E. Malinowska, L. Gawart, P. Parzuchowski, G. Rokicki and Z. Brzozka, Anal. Chim. Acta, 2000, 421, 93.

26 E. E. Eliser, Synthesis and Characterization of Aminoderived $t$-butyl-calix[4]arene Bonded Phases for HPLC, Electronic Thesis or Dissertation, Youngstown State University, 2001.

27 A. Solovyov, T. J. Amundsen, J. J. Daniels, Y.-G. Kim and A. Katz, Chem. Mater., 2008, 20(20), 6316.

28 S. Endemir and M. Yilmaz, J. Mol. Catal. B: Enzym., 2009, 58, 29.

29 R. Perrin and S. Harris, in Calixarenes: a versatile class of Macrocyclic Compounds. Part 4. Industrial Applications, ed. J. Vicens and V. Bohmer, Springer, 1991.

30 R. Mildbrat and V. Bohmer, in Calixarenes 2001. Chapter, Calixarenes as Stationary Phases, ed. Z. Asfari, V. Bohmer, J. Harrowfield and J. Vicens, Springer, 2001.

31 F. Danil de Namor, F. J. Sueros Velarde and M. C. Cabaleiro, J. Chem. Soc., Faraday Trans., 1996, 92, 1731.

32 C. D. S. Tomlin, The Pesticide Manual: A World Compendium, British Crop Protection Council, Surrey, 11th edn, 1997. 
33 C. K. Johnson, ORTEP-II. A FortranThermal Ellipsoide Plot Program. Report ORNL-5138, Oak Ridge National Laboratory, Tenneessee, USA, 1976.

34 C. Moore, Removing Herbicides from Water, Highlights in Chemical Technology, RSC, 19/6/2006.

35 D. Barcelo, Sample Handling and Trace Analysis of Pollutants, Elsevier, The Netherlands, 2000.

36 K. Pyrzynska, Herbicides, Theory and Applications, ed. M. Larramendy, In Tech, 2011, ch. 16.

37 Enraf-Nonius (1997-2000), COLLECT. Nonius BV, Delft, The Netherlands.

38 Z. Otwinowski and W. Minor, in Methods in Enzymology, ed. C. W. Carter Jr and R. M. Sweet, Academic Press, New York, 1997, vol. 276, pp. 307-326.

39 G. M. Sheldrick, SHELXS-97. Program for Crystal Structure Resolution, University of Göttingen, Göttingen, Germany, 1997, See also: G. M. Sheldrick, Acta Crystallogr., Sect. A: Found. Crystallogr., 1990, 46, 467.

40 G. M. Sheldrick, SHELXL-97. Program for Crystal Structures Analysis, University of Göttingen, Göttingen, Germany, 1997, See also: G. M. Sheldrick, Acta Crystallogr., Sect. A: Found. Crystallogr., 2008, 64, 112.
41 V. Bocchi, D. Fiona, A. Pochini, R. Ungaro and G. D. Andreetti, Tetrahedron, 1982, 38, 373.

42 C. D. Gutsche and l. G. Lin, Tetrahedron, 1986, 42, 1633.

43 E. J. Kim, J. Choe and S. Chang, Tetrahedron Lett., 2003, 44, 5299.

44 V. Arora, H. M. Chawla and A. Santra, Tetrahedron, 2002, 58, 5591.

45 Y. K. Lee, Y. K. Ryu, B. E. Kim and J. H. Park, Chromatographia, 1997, 46, 507.

46 E. M. Soliman, M. E. Mohmoud and S. A. Ahmed, Talanta, 2001, 54, 243.

47 A. Pelter, R. M. Rosser and S. Mills, J. Chem. Soc., Perkin Trans. 1, 1984, 717.

48 D. Hafenbradl, M. Keller, G. Wachtershauser and K. O. Stetter, Tetrahedron Lett., 1995, 36, 5179-5182.

49 C. Huber and G. Wachtershauser, Tetrahedron Lett., 2003, 44, 1695.

50 J. J. Christensen, R. M. Izatt and I. D. Hansen, Rev. Sci. Instrum., 1965, 36, 779.

51 J. O. Hill, G. Ojelund and I. Wadso, J. Chem. Thermodyn., 1969, 1, 111. 